\title{
IMPLEMENTATION OF TEAMS GAMES TOURNAMENT (TGT) MODEL TO IMPROVE MOTIVATION IN LEARNING MATHEMATICS
}

\author{
Fitriastuti, Siti Kamsiyati, Karsono
}

Universitas Sebelas Maret

fitriastuti185@gmail.com

\section{Article History}

accepted 09/07/2018

approved 01/08/2018

published 17/09/2018

\section{Keywords}

Motivation in learning

mathematics, Teams

Games Tournament (TGT)

\begin{abstract}
Motivation in learning is an important element in the learning activities. Motivation in learning mathematics of grade fifth student of State Primary School of Makamhaji 03 were still low. The purpose of the research is to improve motivation in learning mathematics in fifth grade students of State Primary School of Makamhaji 03 in the academic year 2017-2018. This research form is Classroom Action Research and it was conducted in two cycles. Each cycle consists of four step, there are planning, acting, observing, and reflecting. The research subject is the fifth grade students of State Primary School of Makamhaji 03 in the academic year 2017/2018 consists of 20 students. Technique of the data collecting used interview, observation, questionnaire, and documentation. Data validity were construct validity, content validity, and triangulation of technique. Data analysis were descriptive comparative statistics, critical analysis, and interactive analysis. Result of this research indicate that the motivation of learning mathematics of grade fifth student of State Primary School of Makamhaji 03 from preaction until cycle II meeting 2 has increased to $90 \%$. The conclusion of this research indicate that through Teams Games Tournament (TGT) model can improve motivation in learning mathematics in fifth grade students of State Primary School of Makamhaji 03 in the academic year 2017/2018.
\end{abstract}

Social, Humanities, and Education Studies (SHEs): Conference Series https://jurnal.uns.ac.id/shes
p-ISSN 2620-9284 e-ISSN 2620-9292 


\section{PENDAHULUAN}

Matematika adalah salah satu mata pelajaran yang diajarkan di semua jenjang Pendidikan terutama di sekolah dasar (SD). Mata pelajaran matematika merupakan ilmu pasti yang berguna untuk kepentingan hidup pada lingkungan, mengembangkan pola pikir, dan sebagai dasar untuk mempelajari ilmu-ilmu yang lain. Pembelajaran matematika bertujuan membantu siswa untuk dapat berpikir kritis, analitis, logis dan kreatif. Mata pelajaran ini sangat penting bagi siswa sebagai bekal siswa menjalani kehidupan. Dengan adanya pelajaran matematika diharapkan siswa dapat memecahkan masalah dalam kehidupan sehari-hari yang berhubungan dengan angka dan matematika.

Menurut Sardiman (2014) Untuk dapat memperoleh hasil belajar matematika yang baik, perlu adanya motivasi belajar yang merupakan faktor psikis yang bersifat nonintelektual yang berperan dalam hal menumbuhkan gairah, perasaan senang dan semangat untuk belajar. Hal ini juga diperkuat oleh pendapat Aritonang (2008) yang mengemukakan bahwa faktor utama yang mempengaruhi hasil belajar siswa adalah minat, motivasi belajar dan guru. Motivasi belajar merupakan pendorong dan penggerak seseorang melakukan kegiatan belajar untuk mencapai tujuan yang diinginkan. Untuk dapat belajar dengan baik, diperlukan motivasi belajar yang baik pula. Dengan adanya motivasi belajar yang baik, maka kegiatan belajar akan berhasil karena siswa disertai dengan rasa gembira. Menurut Sardiman (2014) dalam belajar, sangat diperlukan adanya motivasi, hasil belajar akan menjadi optimal jika ada motivasi belajar yang berperan sebagai pendorong seseorang dalam melakukan kegiatan belajar. Tanpa adanya motivasi belajar pada siswa maka tidak akan ada aktivitas belajar yang dilakukan.

Motivasi belajar matematika di kelas VA SD Negeri 03 Makamhaji Sukoharjo masih rendah. Hal tersebut dibuktikan dengan hasil observasi aktivitas siswa pada pembelajaran matematika ditemukan kenyataan antara lain: 1) tidak adanya hasrat dan keinginan belajar dalam diri siswa yang ditunjukkan dengan tidak aktifnya siswa dalam pembelajaran, hanya sekitar 5 - 8 siswa dari 20 siswa yang aktif mengemukakan pendapat dan menjawab permasalahan yang diberikan guru, sedangkan siswa lain hanya pasif; 2) kurangnya dorongan dan kebutuhan siswa dalam belajar yang dapat dilihat dari kegiatan siswa dalam pembelajaran ketika mengalami kesulitan dalam mengerjakan tugas siswa enggan untuk membuka buku sumber materi dan bahkan ada siswa yang tidak memiliki buku sumber materi; 3) Hanya 3 siswa dari 20 siswa di dalam kelas yang mengajukan pertanyaan kepada guru mengenai materi yang belum dipahami; 4) tidak ulet menghadapi kesulitan yang dibuktikan dengan adanya siswa yang mudah putus asa ketika tidak dapat mengerjakan soal yang diberikan oleh guru di papan tulis, siswa yang salah menjawab soal tidak mau mengerjakan soal kembali; 5) tidak mempunyai orientasi ke masa depan yang dapat dilihat dengan mayoritas siswa di kelas yang kurang antusias, menguap karena mengantuk pada saat mengikuti pembelajaran matematika.

Hasil observasi tersebut diperkuat dengan wawancara dengan guru kelas VA mengenai pelaksanaan pembelajaran matematika pada kelas VA SD Negeri 03 Makamhaji Sukoharjo. Dalam pelaksanaan pembelajaran matematika masih jarang menggunakan model pembelajaran inovatif yang tepat untuk pembelajaran matematika, sehingga siswa kurang antusias mudah bosan, dan kurang semangat. Dalam menyampaikan materi pembelajaran matematika guru masih menggunakan model pembelajaran yang konvensional yaitu menyampaikan materi dengan ceramah dan penugasan untuk memperoleh nilai pada pembelajaran matematika. Wawancara dengan siswa kelas VA juga membuktikan bahwa mayoritas siswa tidak menyukai pembelajaran matematika karena sulit dan bosan ketika mengikuti pembelajaran matematika di kelas sehingga siswa sering mengantuk dan mudah menyerah ketika tidak bisa mengerjakan soal matematika yang sulit. 
Rendahnya motivasi belajar matematika siswa kelas VA SD Negeri 03 Makamhaji Sukoharjo juga dibuktikan dengan rendahnya nilai hasil pengukuran angket motivasi belajar matematika siswa. Ditemukan data bahwa hanya $10 \%$ siswa atau 2 siswa tergolong dalam kategori motivasi tinggi dengan nilai angket motivasi belajar pada rentang 61 - 78; 70\% siswa atau 14 siswa tergolong dalam kategori rendah dengan nilai angket motivasi belajar pada rentang 42 - 60 ; serta $20 \%$ siswa atau 4 siswa tergolong dalam kategori sangat rendah dengan nilai angket motivasi belajar pada rentang 24 - 42. Di kelas VA SD Negeri 03 Makamhaji Sukoharjo tidak terdapat siswa dengan kategori motivasi belajar sangat tinggi. Artinya, hanya 10\% siswa atau 2 siswa yang memiliki motivasi belajar tinggi, sedangkan $90 \%$ siswa atau 18 siswa memiliki motivasi belajar yang relatif rendah. Selain itu, rendahnya motivasi belajar pada pembelajaran matematika terbukti dengan rata-rata nilai angket motivasi belajar hanya sebesar 43 yang tergolong ke dalam kategori motivasi belajar rendah.

Motivasi belajar matematika pada penelitian ini yaitu keseluruhan daya penggerak dan dorongan dalam pribadi seseorang baik internal maupun eksternal yang ditandai dengan timbulnya perasaan untuk melakukan perubahan tingkah laku dalam kegiatan belajar matematika yang ditujukan untuk dapat mencapai tujuan dalam belajar yang ditandai dengan adanya beberapa aspek dalam diri siswa yakni adanya hasrat dan keinginan untuk berhasil, adanya dorongan dan kebutuhan belajar, tekun dalam menghadapi tugas, ulet menghadapi kesulitan, mempunyai orientasi ke masa depan, dan senang mencari dan memecahkan masalah yang dapat dilihat pada diri siswa pada saat mengikuti pembelajaran matematika di kelas VA SD Negeri 03 Makamhaji Sukoharjo tahun ajaran 2017/2018.

Untuk mengatasi rendahnya motivasi belajar matematika siswa kelas VA SD Negeri 03 Makamhaji Sukoharjo, maka peneliti menerapkan model pembelajaran Teams Games Tournament (TGT) sebagai upaya untuk menciptakan kegiatan pembelajaran yang menyenangkan dan kondusif bagi siswa. Menurut Shoimin (2016) model pembelajaran Teams Games Tournament (TGT) merupakan salah satu model pembelajaran kooperatif yang aktif, mudah diterapkan karena melibatkan aktivitas seluruh siswa tanpa adanya perbedaan status yang memungkinkan siswa belajar lebih tenang, menumbuhkan kerja sama dan tanggung jawab, persaingan sehat, keterlibatan belajar dan penghargaan kelompok.

Model pembelajaran Teams Games Tournament (TGT) dalam pembelajaran matematika mengajak siswa untuk belajar dengan kegiatan yang menyenangkan sehingga dapat meningkatkan motivasi belajar siswa dalam pembelajaran matematika. Hal ini sesuai dengan kelebihan model pembelajaran Teams Games Tournament (TGT) yaitu : 1) Membuat peserta didik lebih bersemangat dalam mengikuti pelajaran, karena dalam pembelajaran ini guru menjanjikan sebuah penghargaan pada peserta didik atau kelompok terbaik; 2) Membuat peserta didik menjadi lebih senang dalam mengikuti pelajaran karena ada kegiatan permainan berupa turnamen; 3) Membuat peserta didik yang cerdas berkemampuan akademis tinggi lebih menonjol dalam pembelajaran, tetapi peserta didik yang berkemampuan akademi lebih rendah juga ikut aktif dan mempunyai peranan penting dalam kelompoknya; 4) Menumbuhkan rasa kebersamaan dan saling menghargai sesama anggota kelompoknya.

Berdasarkan uraian tersebut, rumusan masalah dalam penelitian ini yakni apakah penerapan model pembelajaran Teams games Tournament (TGT) dapat meningkatkan motivasi belajar matematika siswa kelas VA SD Negeri 03 Makamhaji Sukoharjo tahun ajaran 2017/2018? Tujuan penelitian ini adalah untuk meningkatkan motivasi belajar matematika dengan menerapkan model pembelajaran Teams games Tournament (TGT) pada siswa kelas VA SD Negeri 03 Makamhaji Sukoharjo tahun ajaran 2017/2018. 


\section{METODE}

Penelitian ini dilaksanakan di SD Negeri 03 Makamhaji Sukoharjo. Penelitian dilaksanakan dalam jangka waktu 5 bulan, yaitu pada bulan Desember 2017-April 2018. Subjek penelitian ini adalah seorang guru dan siswa kelas VA SD Negeri Makamhaji 03 tahun ajaran 2017/2018, berjumlah 20 siswa, yang terdiri dari: 8 siswa laki-laki dan 12 siswa perempuan. Teknik pengumpulan data utama pada penelitian ini adalah wawancara yang terdiri dari wawancara sebelum tindakan dan sesudah tindakan dengan guru dan siswa serta angket motivasi belajar matematika siswa yang terdiri dari 24 pernyataan sesuai dengan indikator motivasi belajar yang harus diisi oleh siswa secara mandiri tidak dipengaruhi orang lain pada setiap pertemuan, observasi dan dokumentasi. Teknik analisis data menggunakan model analisis interaktif analisis data deskriptif komparatif, dan analisis kritis. Uji validitas pada penelitian ini menggunakan validitas isi, validitas konstruk, dan triangulasi teknik. Penelitian ini menggunakan prosedur penelitian yang dilakukan melalui 2 siklus, dan setiap siklus terdiri dari 2 pertemuan. Prosedur penelitian ini terdiri dari beberapa tahapan yaitu perencanaan, pelaksanaan, tindakan, pengamatan/observasi, refleksi.

\section{HASIL DAN PEMBAHASAN}

Berdasarkan hasil nilai angket motivasi belajar matematika siswa pada sebelum adanya tindakan, siklus I, dan siklus II maka dapat disajikan distribusi skor angket motivasi belajar siswa pada mata pelajaran matematika adalah sebagai berikut:

Tabel 1. Distribusi Skor Angket Motivasi Belajar Siswa pada Mata Pelajaran Matematika Pratindakan, Siklus I, dan Siklus II

\begin{tabular}{|c|c|c|c|c|c|c|c|}
\hline \multirow{3}{*}{ No. } & \multirow{3}{*}{$\begin{array}{l}\text { Interval } \\
\text { Skor } \\
\text { Angket }\end{array}$} & \multirow{3}{*}{$\begin{array}{c}\text { Kategori } \\
\text { Motivasi Belajar }\end{array}$} & \multicolumn{5}{|c|}{ Jumlah Siswa } \\
\hline & & & & P 1 & P 2 & P 1 & P 2 \\
\hline & & & Tindakan & Siklus & Siklus & $\underset{\|}{\text { Siklus }}$ & $\underset{\text { Siklus }}{\text { Sil }}$ \\
\hline 1 & $24-42$ & Sangat Rendah & 4 & 0 & 1 & 0 & 0 \\
\hline 2 & $43-60$ & Rendah & 14 & 8 & 3 & 2 & 2 \\
\hline 3 & $61-78$ & Tinggi & 2 & 11 & 15 & 12 & 10 \\
\hline 4 & $79-96$ & Sangat Tinggi & 0 & 1 & 1 & 6 & 8 \\
\hline \multirow{2}{*}{\multicolumn{3}{|c|}{$\begin{array}{l}\text { Persentase Motivasi Rendah } \\
\text { Persentase Motivasi Tinaai }\end{array}$}} & $90 \%$ & $40 \%$ & $20 \%$ & $10 \%$ & $10 \%$ \\
\hline & & & $10 \%$ & $60 \%$ & $80 \%$ & $90 \%$ & $90 \%$ \\
\hline \multicolumn{3}{|c|}{$\begin{array}{c}\text { Persentase Motivasi Tinggi } \\
\text { Jumlah }\end{array}$} & 20 & 20 & 20 & 20 & 20 \\
\hline
\end{tabular}

Selain menggunakan angket motivasi belajar matematika siswa, peneliti juga menggunakan lembar observasi aktivitas siswa. Hasil skor observasi aktivitas siswa pada pembelajaran matematika pada saat sebelum tindakan, siklus I dan siklus II dapat dilihat pada Tabel 2 dibawah ini.

Tabel 2. Distribusi Skor Observasi Aktivitas Siswa pada Mata Pelajaran Matematika Pratindakan, Siklus I, dan Siklus II

\begin{tabular}{cccccccc}
\hline No. $\begin{array}{c}\text { Interval } \\
\text { Skor } \\
\text { Observasi }\end{array}$ & $\begin{array}{c}\text { Kategori } \\
\text { Motivasi } \\
\text { Belajar }\end{array}$ & $\begin{array}{c}\text { Pra } \\
\text { Tindakan }\end{array}$ & $\begin{array}{c}\text { P 1 } \\
\text { Siklus } \\
\text { I }\end{array}$ & $\begin{array}{c}\text { S 2 } \\
\text { Siklus }\end{array}$ & $\begin{array}{c}\text { P 1 } 1 \\
\text { Siklus } \\
\text { II }\end{array}$ & $\begin{array}{c}\text { P 2 } \\
\text { Siklus } \\
\text { II }\end{array}$ \\
\hline 1. & $12-24$ & Sangat Rendah & 8 & 6 & 0 & 4 & 0 \\
2. & $25-36$ & Rendah & 10 & 10 & 8 & 3 & 4 \\
3. & $37-48$ & Tinggi & 2 & 4 & 10 & 13 & 6 \\
4. & $49-60$ & Sangat Tinggi & 0 & 0 & 2 & 0 & 10 \\
Persentasi Motivasi Rendah & $90 \%$ & $80 \%$ & $40 \%$ & $35 \%$ & $20 \%$ \\
& Persentase Motivasi Tinggi & $10 \%$ & $20 \%$ & $60 \%$ & $65 \%$ & $80 \%$ \\
\multicolumn{2}{c}{ Jumlah } & 20 & 20 & 20 & 20 & 20 \\
\hline
\end{tabular}


Berdasarkan Tabel 1 dan Tabel 2 tersebut dapat diperoleh informasi bahwa terjadi peningkatan motivasi belajar matematika siswa. Berdasarkan nilai angket motivasi belajar siswa dan nilai hasil observasi aktivitas siswa pada sebelum tindakan, jumlah siswa yang memiliki motivasi belajar matematika dalam kategori tinggi hanya 2 siswa atau $10 \%$. Sedangkan sisanya yaitu 18 siswa atau $80 \%$ siswa memiliki motivasi belajar matematika dalam kategori rendah dan sangat rendah. Rendahnya motivasi belajar matematika siswa pada sebelum tindakan dikarenakan belum diterapkannya model pembelajaran yang inovatif oleh guru kelas sehingga siswa memiliki motivasi rendah dalam pembelajaran matematika. Selain itu, rendahnya motivasi belajar matematika siswa juga dapat dilihat dari rendahnya aspek motivasi belajar matematika dalam diri siswa. Aspek yang masih rendah dan belum ada pada siswa yakni belum adanya hasrat dan keinginan untuk berhasil karena siswa belum aktif mengemukakan pendapat dalam kelompok diskusi, belum adanya dorongan dan kebutuhan belajar karena siswa tidak aktif bertanya kepada guru tentang materi yang belum dipahami, siswa belum tekun dalam menghadapi tugas karena siswa belum mengerjakan tugas yang diberikan guru, siswa tidak ulet dalam menghadapi kesulitan karena siswa mudah menyerah dalam mengerjakan tugas matematika, siswa belum mempunyai orientasi ke masa depan karena siswa tidak memiliki target nilai dalam pembelajaran matematika, dan siswa tidak senang memecahkan masalah karena siswa belum mengerjakan tugas dari guru dengan tepat waktu.

Pada siklus I, mengalami peningkatan motivasi belajar matematika siswa. Peningkatan terjadi pada setiap pertemuan pada siklus I, berdasarkan nilai angket pada pertemuan 1 siklus I jumlah siswa yang memiliki motivasi belajar matematika dalam kategori tinggi atau sangat tinggi meningkat menjadi 60\% atau 12 siswa. Berdasarkan nilai observasi aktivitas siswa pada pertemuan 1 siklus I jumlah siswa yang memiliki motivasi belajar matematika dalam kategori tinggi atau sangat tinggi meningkat menjadi $20 \%$ atau 4 siswa. Pada pertemuan 2 siklus I berdasarkan nilai angket, jumlah siswa yang memiliki motivasi belajar matematika dalam kategori tinggi atau sangat tinggi meningkat menjadi $80 \%$ atau 16 siswa. Sedangkan dari hasil nilai observasi aktivitas siswa pada pertemuan 1 siklus I jumlah siswa yang memiliki motivasi belajar matematika dalam kategori tinggi atau sangat tinggi meningkat menjadi $65 \%$ atau 13 siswa. Peningkatan motivasi belajar matematika siswa pada siklus I ini dikarenakan beberapa aspek yang belum nampak pada siswa sebelum adanya tindakan sudah mulai terlihat karena diterapkannya model pembelajaran Teams Games Tournament (TGT). Aspek yang mengalami peningkatan adalah pada aspek adanya hasrat dan keinginan untuk berhasil siswa sudah mulai aktif memperhatikan penjelasan guru dalam pembelajaran dan aktif mengemukakan pendapat dalam kelompok diskusi, pada aspek mempunyai orientasi ke masa depan siswa mempunyai harapan dan cita-cita yang tinggi pada pembelajaran matematika karena mempunyai target bisa meraih nilai di atas KKM , dan yang terakhir pada aspek senang mencari dan memecahkan masalah siswa antusias pada saat guru memberikan soal dalam kuis yang dikerjakan secara bergilir di papan tulis.

Pada siklus II, motivasi belajar matematika siswa semakin baik dan terus meningkat dibandingkan pada siklus I. Berdasarkan nilai angket pada pertemuan 1 dan 2 siklus II, jumlah siswa yang mempunyai motivasi belajar matematika dalam kategori tinggi atau sangat tinggi meningkat menjadi 90\% atau 18 siswa. Sedangkan berdasarkan nilai hasil observasi aktivitas siswa, pada pertemuan 1 siklus II jumlah siswa yang memiliki motivasi belajar matematika tinggi sebesar $65 \%$ atau 13 siswa dan pada pertemuan 2 siklus II sebesar $80 \%$ atau 16 siswa. Peningkatan ini membuktikan bahwa pada siklus II indikator penelitian sudah tercapai. Dengan tercapainya indikator penelitian pada siklus II maka tindakan dicukupkan pada siklus II. Peningkatan motivasi belajar matematika siswa pada siklus II dikarenakan guru sudah menerapkan model pembelajaran Teams Games Tournament (TGT) dengan baik. Siswa sudah 
mampu mengikuti kegiatan pembelajaran matematika dengan baik yang ditandai dengan sudah tercapainya semua aspek motivasi belajar matematika pada siswa dalam kegiatan pembelajaran matematika di kelas.

Motivasi belajar matematika siswa juga berpengaruh terhadap hasil belajar matematika siswa. Semakin tinggi motivasi belajar matematika siswa, semakin tinggi pula hasil belajar matematika siswa. Hal ini dibuktikan dengan hasil nilai evaluasi siswa pada setiap pertemuan pada 2 siklus dibandingkan dengan sebelum diterapkannya model pembalajaran Teams Games Tournament (TGT). Distribusi nilai evaluasi belajar siswa dapat dilihat pada Tabel 3 di bawah ini.

\begin{tabular}{|c|c|c|c|c|c|c|}
\hline \multirow[b]{2}{*}{ No. } & \multirow[b]{2}{*}{ Nilai } & \multicolumn{5}{|c|}{ Frekuensi Siswa } \\
\hline & & $\begin{array}{c}\text { Pra } \\
\text { Tindakan }\end{array}$ & $\begin{array}{c}\text { P } 1 \\
\text { Siklus I }\end{array}$ & $\begin{array}{c}\text { P } 2 \\
\text { Siklus I }\end{array}$ & $\begin{array}{c}\text { P 1 } \\
\text { Siklus II }\end{array}$ & $\begin{array}{c}\text { P } 2 \\
\text { Siklus II }\end{array}$ \\
\hline 1 & 40 & - & 1 & - & - & 1 \\
\hline 2 & 45 & - & 2 & - & - & - \\
\hline 3 & 50 & 4 & - & - & - & - \\
\hline 4 & 55 & - & 2 & - & - & - \\
\hline 5 & 60 & 3 & 1 & 1 & - & - \\
\hline 6 & 65 & 1 & 1 & 2 & - & - \\
\hline 7 & 70 & 4 & 1 & 2 & 3 & 1 \\
\hline 8 & 75 & 2 & 2 & 2 & - & - \\
\hline 9 & 80 & 3 & 2 & 2 & 4 & 4 \\
\hline 10 & 85 & 1 & 3 & 3 & - & - \\
\hline 11 & 90 & 2 & 3 & 5 & 7 & 6 \\
\hline 12 & 95 & - & 2 & 1 & - & - \\
\hline \multirow[t]{6}{*}{13} & 100 & - & - & 2 & 6 & 8 \\
\hline & lah & 20 & 20 & 20 & 20 & 20 \\
\hline & rtinggi & 90 & 95 & 100 & 100 & 100 \\
\hline & rendah & 50 & 40 & 60 & 70 & 50 \\
\hline & ta-rata & 69 & 73 & 82 & 88 & 89 \\
\hline & n Klasikal & $40 \%$ & $60 \%$ & $75 \%$ & $85 \%$ & $90 \%$ \\
\hline
\end{tabular}

Berdasarkan Tabel 3, dapat diperoleh data bahwa terjadi peningkatan hasil belajar matematika siswa pada sebelum tindakan, siklus I, dan siklus II. Pada sebelum tindakan, ketuntasan kelas hanya sebesar $40 \%$ atau hanya 8 siswa yang mempunyai nilai evaluasi di atas KKM yaitu 75 dengan nilai rata-rata kelas sebesar 69 . Rendahnya nilai hasil belajar matematika ini disebabkan oleh rendahnya motivasi belajar siswa pada pembelajaran matematika. Karena rendahnya motivasi belajar tersebut mengakibatkan siswa tidak suka dengan matematika, kurang antusias mengikuti pembelajaran matematika di kelas, dan mudah menyerah ketika mengalami kesulitan. Selain itu, guru juga belum menerapkan model pembelajaran yang sesuai dengan karakter dan kesulitan yang dimiliki siswa.

Pada siklus I, terjadi peningkatan hasil belajar matematika siswa. Pada pertemuan 1 siklus I, ketuntasan klasikal sebesar 60\% atau 12 siswa mencapai nilai evaluasi di atas KKM dengan nilai rata-rata kelas 73. Pada pertemuan 2 siklus I terjadi peningkatan hasil belajar matematika siswa dengan ketuntasan klasikal sebesar $75 \%$ atau 15 siswa mencapai nilai evaluasi di atas KKM dengan nilai rata-rata 82. Peningkatan hasil belajar matematika siswa pada siklus I disebabkan meningkatnya motivasi belajar siswa. Pada siklus I, siswa mulai senang mengikuti kegiatan pembelajaran matematika dan senang menyelesaikan kesulitan yang dihadapi di kelas.

Pada siklus II, terjadi peningkatan hasil belajar matematika siswa dibandingkan dengan siklus I. Pada pertemuan 1 siklus II, ketuntasan klasikal sebesar 85\% atau 17 
siswa mencapai nilai evaluasi di atas KKM dengan nilai rata-rata 88. Pada pertemuan 2 siklus II terjadi peningkatan hasil belajar matematika siswa dengan ketuntasan klasikal sebesar $90 \%$ atau 18 siswa mencapai nilai evaluasi di atas KKM dengan nilai rata-rata 89. Peningkatan hasil belajar matematika siswa pada siklus II dikarenakan siswa sudah menguasai materi pada pembelajaran matematika dengan diterapkannya model pembelajaran Teams Games Tournament (TGT). Dengan diterapkannya kegiatan pembelajaran sesuai model pembelajaran Teams Games Tournament (TGT) ini siswa menjadi senang dan termotivasi untuk mengikuti pembelajaran matematika di kelas.

Meningkatnya motivasi belajar matematika siswa melalui penerapan model pembelajaran Teams Games Tournament (TGT) sesuai dengan hasil penelitian oleh Eka Bagus Widiastutik (2013) yaitu model pembelajaran Teams Games Tournament (TGT) merupakan model pembelajaran yang mampu meningkatkan keaktifan siswa di kelas dan mampu menciptakan suasana pembelajaran yang menyenangkan sehingga berpengaruh terhadap motivasi belajar matematika dan hasil belajar matematika siswa.

\section{SIMPULAN}

Berdasarkan hasil penelitian tindakan kelas yang telah dilaksanakan selama dua siklus yang setiap siklusnya terdiri dari dua pertemuan dapat ditarik kesimpulan bahwa melalui penerapan model pembelajaran Teams Games Tournament (TGT) dapat meningkatkan motivasi belajar matematika siswa kelas VA SD Negeri 03 Makamhaji Sukoharjo tahun ajaran 2017/2018. Peningkatan tersebut dibuktikan dengan meningkatnya nilai angket motivasi belajar matematika dan nilai hasil observasi aktivitas siswa pada setiap pertemuannya. Hasil penelitian ini dapat digunakan oleh guru untuk menciptakan pembelajaran yang bermakna, inovatif dan tepat sehingga dapat meningkatkan kualitas pembelajaran dan meningkatkan motivasi belajar siswa khususnya pada pembelajaran matematika di kelas.

\section{DAFTAR PUSTAKA}

Imdad Ullah, dkk. (2013). Factors Influencing Students Motivation to Learn in Bahauddin Zakariya University, Multan (Pakistan). International Journal of Human Resource Studies, 3 (2), 91.

Nopita Sitorus dan Edysurya (2017). The Influence of Teams Games Tournament Cooperative Learning Model on Students' Creativity Learning. International Journal of Sciences : Basic and Applied Research (IJSBAR). 34 (1). 18.

Saefullah. (2012). Psikologi Perkembangan dan Pendidikan. Bandung : CV Pustaka Setia.

Sardiman. (2014). Interaksi dan Motivasi Belajar Mengajar. Jakarta : Rajawali Press.

Shoimin, Aris. (2016) . 68 Model Pembelajaran Inovatif dala Kurikulum 2013. Yogyakarta: Ar ruzz Media.

Sulisworo dan Fadiyah Suryani (2014). The effect Of Cooperative Learning, Motivation and Information Technology Literacy to Achievement. International Journal of Learning \& Development. 4 (2), 60. 